Bono, G., Castello, D., and Crosato, M. (1963). Minerva pediat., 15, 1097.

Buchanan, W. W., Crooks, J., Alexander, W. D., Koutras, D. A., Wayne, E. J., and Gray, K. G. (1961) Lancet, 1, 245.

Bunim, J. J. (1961). Ann. rheum. Dis., 20, 1.

Burnham, T. K., Neblett, T. R., and Fine, G. (1963). 7. invest. Derm., 41, 451.

Burrell, R. G. (1963). Amer. Rev. resp. Dis., 87, 389.

Caplan, A. (1953). Thorax, 8, 29.

Payne, R. B., and Withey, J. L. (1962). Ibid., 17, 205.

Cormane, R. H. (1964). Lancet, 1, 534.

Dixon, F. J. (1963). Harvey Lect., 58, 21.

Doniach, D., and Roitt, I. M. (1963). In Clinical Aspects of Immunology, edited by P. H. G. Gell and R. R. A. Coombs. Blackwell, Oxford.

Dresner, E., and Trombly, P. (1959). New Engl. F. Med., 261, 981.

Edwards, J. E., and Burchell, H. B. (1951). Arch. intern. Med., 87, 372 .

Ellman, P., and Ball, R. E. (1948). Brit. med. Y., 2, 816.

Faber, V., Elling, P., Norup, G., Mansa, B., and Nissen, N. I. (1964). Lancet, 2, 344.

Forbes, I. J. (1958). Aust. Ann. Med., 7, 205.

Franklin, E. C. Zucker-Franklin, D., and McEwen, C. (1959). Arch. interamer. Rheum. (Rio de, .), $2,250$.

Geld, H. van der, Feltkamp, T. E. W., Loghem, J. J. van., Oosterhuis, H. J. G. H., and Biemond, A. (1963). Lancet, 2, 373 .

Hamman, L., and Rich, A. R. (1944). Bull. fohns Hopk. Hosp., 74, 117. Hayman, L. D., and Hunt, R. E. (1952). Dis. Chest, 21, 691.

Hennes, A. R., Moore, M. Z., Carpenter, R. L., and Hammarsten, J. F. (1961). Amer. Rev. resp. Dis., 83, 354.
Heppleston, A. G. (1956). Thorax, 11, 77.

Hijmans, W., Doniach, D., Roitt, I. M., and Holborow, E. J. (1961). Brit. med. 7., 2, 909.

Hyun, B. H., Diggs, C. L., and Toone, E. C. (1962). Dis. Chest, 42, 449 .

Israel, H. L. (1953). Amer. 7. med. Sci., 226, 387.

Livingstone, J. L., Lewis, J. G., Reid, L., and Jefferson, K. E. (1964). Quart. 7. Med., 33, 71 .

Mackay, I. R., and Burnet, McF. (1963), Autoimmune Diseases.

Thomas, Ilï.

Milgrom, F., and Witebsky, E. (1960). F. Amer. med. Ass., 174, 56

Pernis, B., Vigliani, E. G., Heuer, A., and Cavagna, G. M. (1963). Folia allerg. (Roma), 10, 396.

Price, T. M. L., and Skelton, M. O. (1956). Thorax, 11, 234.

Roitt, I. M., and Doniach, D. (1965). Scientific Basis of Medicine. In press.

Rose, H. M., Ragan, C., Pearce, E., and Lipman, M. O. (1948). Proc. Soc. exp. Biol. (N.Y..), 68, 1 .

Scadding, J. G. (1960). Brit.. med. f., 1, 443.

(1964). Ibid., 2, 686.

Singer, J. M., and Plotz, C. M. (1956). Amer. F. Med., 21, 888.

Taybor, K. B., Roitt, I. M., Doniach, D., Couchman, K. G., and Shapland, C. (1962). Brit. med. 7., 2, 1347 .

Thomas, L. (1964). New Engl. 7. Med., 270, 1157.

Tamasi, T, B., Fudenberg, H. H., and Finby, N. (1962). Amer. $\$$. Med., 33, 243.

Walker, G., Doniach, D., Roitt, I. M., and Sherlock, S. (1965). Lancet. In press.

\title{
Propranolol (Inderal) in Disturbances of Cardiac Rhythm
}

\author{
D. J. ROWLANDS,* M.B., B.SC., M.R.C.P. ; G. HOWITT,* M.D., M.R.C.P., M.R.C.P.ED. ; \\ P. MARKMAN,* M.B., M.R.C.P., M.R.C.P.ED., F.C.P.S.A.
}

Brit. med. Y., 1965, 1, 891-894

Black and Stephenson (1962) reported the results of betaadrenergic-receptor blockade in animals, using pronethalol. They found that the drug induced bradycardia and they indicated the possibility of using it in certain arrhythmias. Stock and Dale (1963) reported its use on patients with various arrhythmias. They found it useful in controlling the ventricular rate in atrial fibrillation and in the treatment of digitalisinduced arrhythmias, and they studied its effect in supraventricular tachycardias and upon various types of ectopic beat. After the production of evidence that the drug is carcinogenic to mice (Paget, 1963) the makers advised that its use should be restricted to those conditions that directly threaten life or to those patients whose life-expectation is short. The development of propranolol (Inderal), which is free from carcinogenic activity in mice (Black, Crowther, Shanks, Smith, and Dornhorst, 1964) and has a therapeutic ratio ten to twenty times greater than pronethalol, has renewed interest in the clinical application of beta-receptor blockade. The present paper reports experiences using propranolol in selected cases of atrial fibrillation, in atrial flutter and tachycardia, and in ventricular arrhythmias.

\section{Atrial Fibrillation}

Eleven patients were studied. Of these, five had rheumatic heart disease, four had thyrotoxicosis, one had mitral stenosis and thyrotoxicosis, and one had no underlying cardiac disorder. The patients with rheumatic heart disease were selected because of failure to control the ventricular rate at rest or on exercise with maximum tolerated doses of digitalis. The patient with idiopathic atrial fibrillation was studied both before and after digitalization. Those patients with thyrotoxicosis had been given digitalis to the maximum tolerated dose.

- Univeraity Department of Cardiology, Manchester Royal Infirmary.
Seven patients were studied before and during steady-state exercise on the cycle ergometer in the supine position. The patients were exercised for four minutes and the heart rate was measured during the last half-minute of exercise. The work load was kept constant for each individual patient. The propranolol was given intravenously in a standard dose of $10 \mathrm{mg}$. The resting rate after the drug was given was taken as the mean of readings at five-minute intervals between 15 and 25 minutes after the injection.

\section{Rheumatic Atrial Fibrillation}

In the six cases studied the ventricular rate was controlled better by the combination of digitalis and propranolol than by digitalis alone (Table I).

It is well recognized clinically that some patients have rapid ventricular rates which are resistant to digitalis therapy. In the presence of mitral stenosis, tachycardia reduces diastolic filling time and may reduce ventricular filling, so causing an

TABLE I.-Ventricular Rate (Per Minute) in Atrial Fibrillation at Rest

\begin{tabular}{|c|c|c|c|c|c|c|c|}
\hline \multirow{3}{*}{$\begin{array}{l}\text { Case } \\
\text { No. }\end{array}$} & & & & \multicolumn{2}{|c|}{ Rest } & \multicolumn{2}{|c|}{ Exercise } \\
\hline & \multirow{2}{*}{\multicolumn{3}{|c|}{ Diagnosis }} & Before & After & Before & After \\
\hline & & & & \multicolumn{2}{|c|}{ Propranolol } & \multicolumn{2}{|c|}{ Propranolol } \\
\hline $\begin{array}{c}1 \\
2 \\
3 \\
4 \\
5 \\
6 * \\
7 \\
8 \\
9 \\
10 \\
11 \dagger \\
11\end{array}$ & $\begin{array}{l}\text { Rheumatic hear } \\
\text { ", } \\
\text { Thyrotoxicosis" } \\
\text { ", } \\
\text { Idiopathic } \\
\text { ". }\end{array}$ & $\begin{array}{l}\mathrm{tdi} \\
\ldots \\
\because \\
\because \\
\therefore \\
\therefore\end{array}$ & 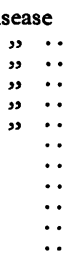 & $\begin{array}{r}117 \\
126 \\
160 \\
204 \\
108 \\
112 \\
132 \\
148 \\
96 \\
156 \\
132 \\
87\end{array}$ & $\begin{array}{r}80 \\
72 \\
96 \\
140 \\
84 \\
72 \\
84 \\
91 \\
66 \\
90 \\
93 \\
63\end{array}$ & $\begin{array}{l}174 \\
158 \\
155 \\
114 \\
189 \\
190 \\
147\end{array}$ & $\begin{array}{r}144 \\
85 \\
110 \\
81 \\
120 \\
153 \\
108\end{array}$ \\
\hline
\end{tabular}


increase in the left atrial pressure. The value of propranolol in these circumstances is well illustrated by the following case:

Case 4 (Table I).-A man aged 59 was first seen at the age of 53 complaining of exertional dyspnoea. He was found to have polycythaemia vera, mitral stenosis, and atrial fibrillation. He was treated with thiotepa, numerous venesections, and digitalis in conventional dosage. In May 1964 he was admitted with pulmonary oedema and congestive heart failure. He was totally disabled and was jaundiced, secondarily to gross hepatic congestion. The cardiac rhythm was atrial fibrillation and the ventricular rate was 220 per minute. For six days he was treated with oral and intramuscular diuretics and with large doses of digoxin $(0.5 \mathrm{mg}$. t.d.s. for three days, followed by $0.25 \mathrm{mg}$. t.d.s.) without any improvement. He was then given $10 \mathrm{mg}$. of propanolol intravenously and the ventricular rate fell from 204 to 140 within 15 minutes. The diuretic therapy and digoxin $(0.25 \mathrm{mg}$. b.d.) were continued, and he was given propranolol $20 \mathrm{mg}$. t.d.s. by mouth. The ventricular rate was maintained between 90 and 100 with occasional escapes of up to 150 per minute. The congestive heart failure cleared completely. Thirty-six days later, when there was no longer any heart failure and the patient was ambulant, the propranolol was stopped, the treatment with digoxin and diuretics being continued unchanged. The apex rate gradually rose again, and after one week was sustained at 160 per minute at rest. A further intravenous injection of propranolol at this stage lowered the ventricular rate to 80 per minute. Thereafter treatment was continued with both digoxin and propranolol, and three months later his heart rate was well controlled, he was fully ambulant, and he was planning to return to light work. There was no clinical or laboratory evidence of thyrotoxicosis in this case.

The reduction in ventricular filling time was clearly critical in the presence of mitral stenosis. The reduction of ventricular rate produced by the drug was of greater importance in these circumstances than the inhibition of the sympathetic inotropic effect, which normally contraindicates its use in congestive heart failure (Stock and Dale, 1963 ; Howitt, Tinker, and Wade, 1965).

\section{Thyrotoxic Atrial Fibrillation}

It is generally acknowledged that the ventricular rate in those cases of atrial fibrillation due to thyrotoxicosis is usually inadequately controlled by digitalis and that effective control cannot be achieved until the thyrotoxicosis is treated. This was so in the five cases studied. After the drug both the resting and the exercise rates were reduced.

It has been noted that beta-receptor blockade in patients with thyrotoxicosis who have sinus rhythm does not reduce the heart rate (Wilson, Theilen, and Fletcher, 1964). So far as we are aware, no observations have previously been made on the effect of beta-receptor blockade in thyrotoxic patients with atrial fibrillation. Further studies on the action of propranolol on thyrotoxicosis are being undertaken.

\section{Idiopathic Atrial Fibrillation}

The single case in this group was the only patient who presented us with the opportunity of studying the effects of propranolol both before and after digitalization. Both digitalis and propranolol reduced the resting and exercise ventricular rates, and the reduction produced by the two drugs together was greater than that produced by either alone.

\section{Atrial Flutter or Tachycardia}

All patients with persistent atrial flutter or tachycardia seen in the department during the period of the study who had no evidence of heart failure were selected for the investigation. Some of the cases were difficult to classify. All had a regular atrial rate, four had a "saw-tooth" pattern of atrial activity, and three had isoelectric intervals betwen the $P$ waves. The atrial rates varied between 170 and 280 . All the patients were receiving digitalis, and all had been treated for a period with maximum tolerated doses of digitalis, in an unsuccessful attempt to alter the rhythm or to increase the degree of atrioventricular block. Case 7 (Table II) was studied before and after digitalization. Six of the patients were exercised, the method used being identical with that for the group with atrial fibrillation.

Results.-The results obtained are at variance with those which Stock and Dale (1963) reported for pronethalol (Table IS). In no instance did we observe any significant change in the atrial rate. All cases showed some increase in the degree of atrioventricular block with consequent reduction in the ventricular rate. Five patients showed a reduction in the ventricular rate at rest. The other two showed no change at rest, but they had low resting ventricular rates initially on digitalis alone. Of the six patients exercised, five had an increase in the ventricular rate during exercise, and in all these cases there was a reduction in the extent of the increase after propranolol was given. In four of the cases this reduction was substantial and was accompanied by a diminution in the troublesome palpitation which the patients experienced during exercise before the drug was given.

TABLE II.-Atrial $(A)$ and Ventricular $(V)$ Rates in Atrial Flutter or Tachycardia Both at Rest and During Exercise, Before and After Propranolol

\begin{tabular}{|c|c|c|c|c|c|c|c|}
\hline \multirow{3}{*}{$\begin{array}{l}\text { Case } \\
\text { No. }\end{array}$} & \multirow{3}{*}{\multicolumn{2}{|c|}{$\begin{array}{c}\text { Associated } \\
\text { Cardiac } \\
\text { Disease }\end{array}$}} & \multirow{3}{*}{$\begin{array}{l}\mathbf{A} \\
\text { or } \\
\text { V }\end{array}$} & \multicolumn{2}{|c|}{ Resting Rate } & \multicolumn{2}{|c|}{ Exercise Rate } \\
\hline & & & & Before & After & Before & After \\
\hline & & & & \multicolumn{2}{|c|}{ Propranolol } & \multicolumn{2}{|c|}{ Propranolol } \\
\hline 12 & \multirow{4}{*}{\multicolumn{2}{|c|}{$\begin{array}{l}\text { Atrial septal defect } \\
\text { Post-operative } \\
\text { Atrial septal defect } \\
\text { Post-operative } \\
\text { Atrial septal defect }\end{array}$}} & \multirow{11}{*}{$\begin{array}{l}\mathbf{A} \\
\mathbf{V} \\
\mathbf{A} \\
\mathbf{V} \\
\mathbf{A} \\
\mathbf{V} \\
\mathbf{A} \\
\mathbf{V} \\
\mathbf{A} \\
\mathbf{V} \\
\mathbf{A} \\
\mathbf{V} \\
\mathbf{A} \\
\mathbf{V} \\
\mathbf{A} \\
\mathbf{V}\end{array}$} & \multirow{11}{*}{$\begin{array}{r}276 \\
69 \\
280 \\
70 \\
260 \\
85 \\
216 \\
90 \\
276 \\
72 \\
170 \\
170 \\
264 \\
132 \\
264 \\
132\end{array}$} & \multirow{11}{*}{$\begin{array}{r}276 \\
69 \\
280 \\
70 \\
255 \\
65 \\
216 \\
72 \\
280 \\
50 \\
170 \\
85 \\
264 \\
84 \\
264 \\
98\end{array}$} & \multirow{8}{*}{$\begin{array}{r}276 \\
96 \\
288 \\
144 \\
260 \\
125 \\
216 \\
108 \\
280 \\
140\end{array}$} & \multirow{8}{*}{$\begin{array}{r}276 \\
69 \\
284 \\
90 \\
255 \\
65 \\
216 \\
105 \\
280 \\
100\end{array}$} \\
\hline 13 & & & & & & & \\
\hline 13 & & & & & & & \\
\hline 14 & & & & & & & \\
\hline 15 & Atrial se & defect & & & & & \\
\hline & Post-ope & re & & & & & \\
\hline 16 & Rheuma & eart & & & & & \\
\hline 17 & " & , & & & & & \\
\hline $18^{*}$ & " & " & & & & 264 & 264 \\
\hline & & 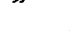 & & & & 132 & 126 \\
\hline 18 & " & & & & & $\begin{array}{l}264 \\
132\end{array}$ & $\begin{array}{l}264 \\
114\end{array}$ \\
\hline
\end{tabular}

* Before digitalization

\section{Ventricular Arrhythmias}

Two patients were seen with repetitive paroxysmal ventricular tachycardia. In these cases electrocardiograms were taken at rest immediately before and 20 minutes after an intravenous injection of $10 \mathrm{mg}$. of propranolol.

Seven patients with frequent spontaneous ectopic beats were also studied. Of these, six had sinus rhythm and one (Case 22, Table III) had atrial fibrillation. None had received digitalis therapy at the time of the study. Of the six patients in sinus rhythm, five had spontaneous ventricular ectopic beats at rest and one (Case 25, Table III) had no ectopic beats at rest but developed bigeminal rhythm on exercise.

After each patient had been lying still for 15 minutes a continuous E.C.G. recording was taken for at least two minutes. The frequency of ectopic beats during recording was expressed as a percentage of the total beats to exclude the effect of changes in heart rate. An intravenous injection of $10 \mathrm{mg}$. of propranolol was then given and the frequency of ectopic beats at rest was again determined over a two-minute period, 20 minutes after the injection.

A method was devised to stimulate the production of ectopic beats, based on the observation by Johnstone (1950) that an increase of the partial pressure of carbon dioxide during anaesthesia may provoke extrasystoles. The effect of the same intravenous dose of propranolol on the induced extrasystoles was studied in four cases. The method used was as follows:

The patients were given a 2-litre bag of $100 \%$ oxygen to rebreathe. They were asked to rebreathe as long as possible, 
TABle III.-Percentage Frequency of Ventricular Ectopic Beats Both at Rest and During Rebreathing Before and After Propranolol. The Calculated Partial Pressure of Carbon Dioxide in Arterial Blood for each Stage is also Included

\begin{tabular}{|c|c|c|c|c|c|c|c|c|c|}
\hline \multirow[b]{2}{*}{$\begin{array}{l}\text { Case } \\
\text { No. }\end{array}$} & \multirow[b]{2}{*}{$\begin{array}{l}\text { Underlying } \\
\text { Disorder }\end{array}$} & \multirow[b]{2}{*}{$\begin{array}{c}\text { Basic } \\
\text { Rhythm }\end{array}$} & \multicolumn{2}{|c|}{ Resting \% Ectopics } & \multicolumn{2}{|c|}{$\%$ Ectopics after Rebreathing } & \multicolumn{3}{|c|}{ Arterial Pcos } \\
\hline & & & $\begin{array}{c}\text { Before } \\
\text { Propranolol }\end{array}$ & $\begin{array}{c}\text { After } \\
\text { Propranolol }\end{array}$ & $\begin{array}{c}\text { Before } \\
\text { Propranolol }\end{array}$ & $\begin{array}{c}\text { After } \\
\text { Propranolol }\end{array}$ & Resting & $\begin{array}{c}\text { During } \\
\text { 1st } \\
\text { Rebreathing } \\
\text { Period }\end{array}$ & $\begin{array}{l}\text { During } \\
\text { Rebreathing } \\
\text { Period after } \\
\text { Propranolol }\end{array}$ \\
\hline $\begin{array}{l}19 \\
20 \\
21 \\
22 \\
23 \\
24 \\
25\end{array}$ & $\begin{array}{l}\text { Ischaemic heart disease } \\
\text { Card̈ } \\
\text { Atriomyopathy } " \\
\text { Atrial septal defect } \\
\text { Ischaemic heart disease } \\
\text { Cardiomyopathy } \\
\text { Ventricular septal defect }\end{array}$ & $\begin{array}{l}\text { Sinus } \\
\text { "” } \\
\text { A."Fib. } \\
\text { Sinus } \\
\text { This" patient } \\
\text { exertion }\end{array}$ & $\begin{array}{c}7 \cdot 7 \\
0 \\
24 \\
3 \\
26 \\
42 \\
\text { ad } 0 \% \text { ectopic }\end{array}$ & $\begin{array}{c}7 \cdot 7 \\
0 \\
25 \\
3 \cdot 5 \\
24 \\
42 \\
\text { ats at rest and }\end{array}$ & $\begin{array}{c}22 \\
26 \\
54 \\
44 \\
\% \text { on exercis }\end{array}$ & $\begin{array}{c}9.5 \\
0 \\
4 \cdot 6 \\
42 \\
\text { After propran }\end{array}$ & $\begin{array}{c}39 \\
42 \\
40 \\
41 \\
\text { was give }\end{array}$ & $\begin{array}{c}47 \\
58 \\
51 \\
56 \\
\text { ectopic beats }\end{array}$ & $\begin{array}{r}51 \\
60 \\
51 \\
51 \\
\text { curred on }\end{array}$ \\
\hline
\end{tabular}

and this was usually between $2 \frac{3}{4}$ and $3 \frac{3}{4}$ minutes. A continuous E.C.G. recording was begun after $1 \frac{1}{2}$ minutes' rebreathing and was continued for 1 minute after the cessation of rebreathing. There was ample oxygen in the bag to ensure that oxygen-lack did not occur. After $1 \frac{1}{2}$ minutes' rebreathing the partial pressure of carbon dioxide $\left(\mathrm{PCO}_{2}\right)$ has risen to approximate closely to that in mixed venous blood (Campbell and Howell, 1960). Thereafter, carbon dioxide continues to accumulate and the final carbon-dioxide content of the bag at the end of the rebreathing period was analysed in the modified Haldane apparatus (Campbell, 1960) and the arterial $\mathrm{PCO}_{2}$ was calculated. The whole rebreathing procedure and $\mathrm{CO}_{2}$ analysis was repeated 40 minutes later, 25 minutes after the intravenous injection of $10 \mathrm{mg}$. of propranolol. The normal resting arterial $\mathrm{PCO}_{2}$ was determined by the rebreathing method of Campbell and Howell (1960).

In repetitive paroxysmal ventricular tachycardia the frequency of the ectopic beats was considerably reduced but the arrhythmia was not completely abolished (Fig. 1).

Exercise-induced bigeminal rhythm was abolished by propranolol (Fig. 2).

The effect of propranolol on frequent ventricular extrasystoles is shown in Table III and Fig. 3. It is apparent that propranolol does not, under the present conditions, affect the spontaneous frequency of ectopic beats at rest.
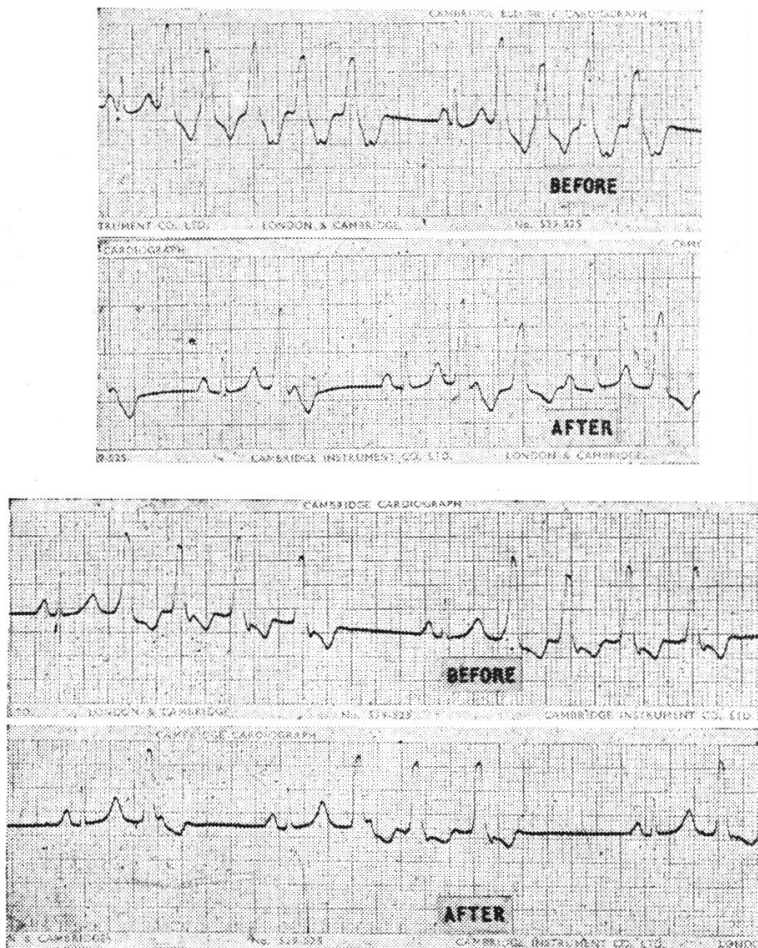

FIG. 1.-Cases 1 and 2. Repetitive paroxysmal ventricular tachycardia. The electrocardiogram before and twenty minutes after intravenous propranolol.
We had anticipated that the induced extrasystoles would occur with greatest frequency during the last few seconds of rebreathing, when the arterial carbon-dioxide tension would be at its peak. This was found not $\mathrm{t} J$ be so: no significant increase in the frequency of ectopic beats occurred until the bag was disconnected and the patient was allowed to breathe room air.
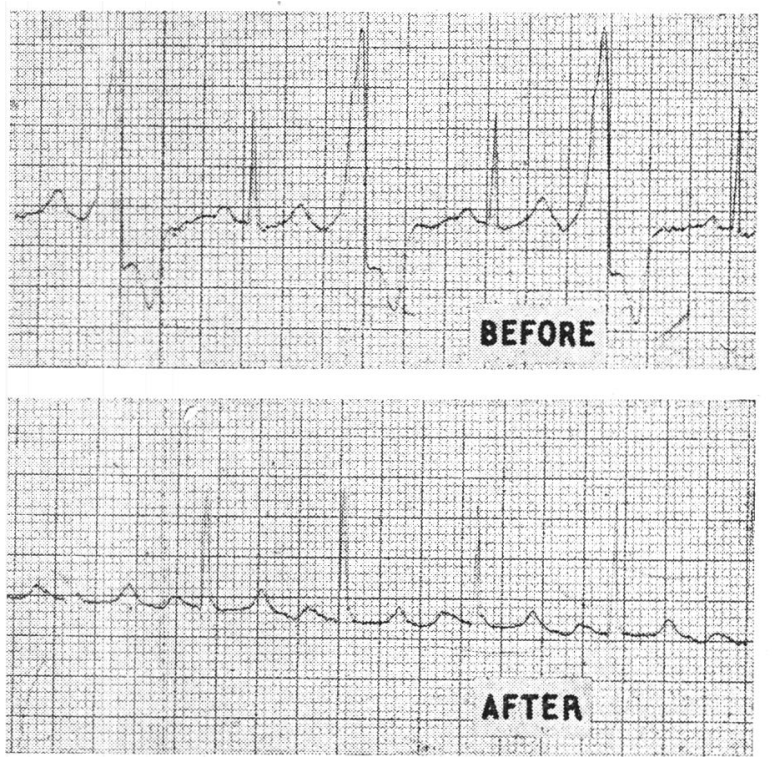

Fig. 2.-Exercise-induced bigeminal rhythm, the electrocardiogram before and twenty minutes after intravenous propranolol.

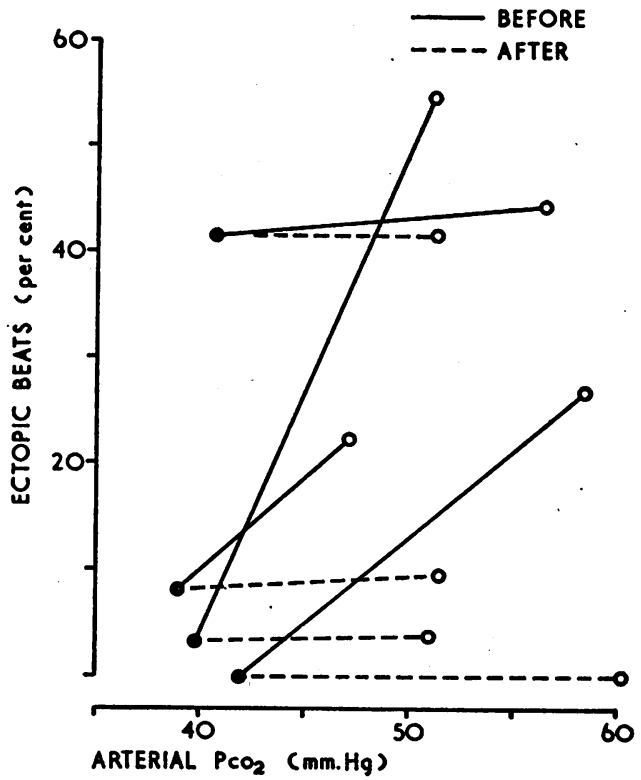

FIG. 3.-Ventricular extrasystoles. The frequency of ectopic beats spontaneously (closed circles) and after re-breathing (open circles). The words "before" and "after" refer to the administration of propranolol. 
By this time the patients were breathing deeply and rapidly and were beginning to feel distressed.

The deep and rapid respiratory excursions continued for many seconds after the bag was disconnected. It was during this period that a striking increase in the frequency of ventricular ectopic beats was observed in three out of the four patients. Consequently, measurements were made of the frequency of ectopic beats during the 15 seconds immediately after disconnexion of the rebreathing bag, and these, before and after the propranolol, are given in Table III. In the three patients in whom it proved possible to provoke additional extrasystoles by this means, similar provocation after the injection of propranolol failed to evoke the response.

Stock and Dale (1963) reported a progressive increase in the coupling-time of the ectopic to the initiating sinus beat, after pronethalol. In four of their six cases this change occurred and was followed by the complete abolition of the extrasystoles. In the present study propanolol had no effect on the couplingtime of the spontaneous ectopic beats, and there was no difference in coupling-times between the induced and the spontaneous extrasystoles.

\section{Discussion}

The observations in cases of atrial fibrillation agree with similar studies on the effect of pronethalol, and particularly with those of Stock and Dale (1963). There was appreciable reduction in the ventricular rate in the undigitalized patient and further slowing in the already digitalized patient. The drug was of particular value to patients with an uncontrolled ventricular rate and obstruction at the mitral valve. Even in the absence of such obstruction, patients whose ventricular rate was poorly controlled after receiving large doses of digitalis benefited from the drug. This applied particularly in cases of thyrotoxicosis before antithyroid treatment had become effective, in which circumstances digitalis-resistance is to be anticipated.

In atrial flutter or tachycardia, propranolol induced a reduction in the ventricular rate when used alone, and further reduced the ventricular rate in the fully digitalized patient. Naturally, least effect was observed in patients who had an adequate degree of atrioventricular block with digitalis alone. The drug was particularly useful in controlling the ventricular rate during exertion, and it may prove of value in cases of atrial flutter or tachycardia when attempts to convert the rhythm have failed and where digitalis alone has failed to control the exercise rate. Its potential value in this respect may be diminished if electrical "cardioversion" is widely used.

The effect of propranolol on repetitive paroxysmal ventricular tachycardia was essentially the same as that described by Stock and Dale (1963) using pronethalol ; that is, there was a reduction in the percentage of ectopic beats and in the overall heart rate, without complete suppression of the ectopic beats.

Exercise-induced bigeminal rhythm occurred in one patient only, but the effect of propranolol in preventing the abnormal rhythm and the distressing palpitation associated with it was striking. This patient has since been given maintenance treatment with oral propranolol, with symptomatic improvement.

The effect of propranolol in patients with frequent ectopic beats is of interest. It did not affect the frequency of spontaneous ectopic beats, but it effectively blocked ectopics induced by the rebreathing procedure; consequently the modes of production of ectopic beats may be different in these two circumstances. The design of the experiment did not make it possible to decide whether the $\mathrm{PCO}_{2}$ or other factors, such as $\mathrm{pH}$, muscular chest-wall movements, or nervous stimuli, initiated the extrasystoles. Whatever the factor involved, the time of occurrence of the greatest number of extrasystoles (immediately after the end of the rebreathing period) suggests that possibly the rate of change of the factor concerned may be the stimulus. If there is any delay in the movement of hydrogen ions or carbon dioxide across cell membranes (Fowle, Matthews, and Campbell, 1964) then any concentration gradients (with their possible effects on the cell membrane) will be at a maximum immediately the rebreathing bag is disconnected, when the arterial $\mathrm{PCO}_{2}$ falls abruptly in a few seconds. Johnstone (1950) has suggested that an increase in the arterial carbon-dioxide tension may evoke extrasystoles. Price et al. (1958) have shown that catecholamine release at nerve-endings, and to a less extent from the adrenal medulla, may occur during procedures that give rise to an increased carbon-dioxide tension in the arterial blood. If such a process occurs it is feasible that those patients who are already prone to spontaneous ventricular extrasystoles may develop ectopic beats as the result of catecholamine release from the cardiac sympathetic nerves. It is also feasible that the effect of such catecholamines may be abolished by the beta-receptor blockade. Whether this is so or not, it may be that the prophylactic use of propranolol in the premedication of patients who have frequent ectopic beats may reduce the risk of ventricular arrhythmias during the subsequent anaesthesia. Payne and Senfield (1964) have suggested the use of pronethalol for this purpose and Johnstone (1964) has used pronethalol in the treatment of ventricular ectopic beats occurring during cyclopropane anaesthesia.

One cautionary note needs to be added: in two patients who had had mild diffuse obstructive airway disease, wheezing and dyspnoea appeared to be aggravated by the use of propranolol. This is an expected result of sympathetic beta blockade.

\section{Summary}

The effect of propranolol has been studied on patients with atrial fibrillation of rheumatic, thyrotoxic, and idiopathic origin. In all cases a reduction in ventricular rate occurred, even in patients already fully digitalized. This may be clinically valuable in digitalized patients with mitral stenosis and persistent tachycardia and in untreated thyrotoxicosis.

In atrial flutter the atrial rate was unaffected, but a significant and consistent reduction in the ventricular rate was induced. especially during exercise.

The frequency of ectopic beats in repetitive paroxysmal ventricular tachycardia was reduced, but the abnormal rhythm was not completely abolished.

In a single case of exercise-induced bigeminal rhythm the abnormality was abolished by the drug.

The frequency of spontaneous ventricular ectopic beats was not reduced, but propranolol prevented the increased frequency induced by a rebreathing procedure.

The drug should be used with caution in patients with diffuse obstructive airway disease.

We wish to thank Dr. A. Morgan Jones and Dr. E. G. Wade for permission to study patients under their care and for helpful advice. We are grateful to the Department of Medical Illustration for preparation of Fig. 3 and to I.C.I. Pharmaceuticals Ltd. for supplies of Inderal.

\section{REFERENCES}

Black, J. W., Crowther, A. F., Shanks, R. G., Smith, L. H., and Dornhorst, A. C. (1964). Lancet, 1, 1080. and Stephenson, J. S. (1962). Ibid., 2, 311

Campbell, E. J. M. (1960). Brit. med. F., 1, 457.

Campbell, Howell, J. B. L. (1960). Ibid., 1, 458.

Fowle, A. S. E., Matthews, C. M. E., and Campbell, E. J. M. (1964) Clin. Sci., 27, 51 .

Howitt, G., Tinker, J., and Wade, E. G. (1965). Ibid. In press.

Howitt, G., Tinker, J., and Wade, E. G. (1965).

Johnstone, M. (1950). Brit. Heart f., 12,

Paget, G. E. (1963). Brit. med. F., 2, 1266.

Payet, G. P. (1963). Brit. med. M. (1964). Ibid., 1, 603.

Price, H. L., Lurie, A. A., Jones, R. E., Price, M. L., and Linde, H. W. (1958). Anesthesiology, 19, 619.

Stock, J. P. P., and Dale, N. (1963). Brit. med. F., 2, 1230.

Stock, J. P. P., and Dale, N. (1963). Brit. med. F., 2, 1230. (1964). F. clin. Invest., 43, 1697. 